\title{
The Black Sea Dating Game and Holocene Marine Transgression
}

\author{
Peta J. Mudie ${ }^{1 *}$, Valentina Yanko-Hombach ${ }^{2}$, Sergei Kadurin ${ }^{2}$ \\ ${ }^{1}$ Earth Sciences Department, Memorial University of Newfoundland, St. Johns, Canada \\ ${ }^{2}$ Department of Physical and Marine Geology, Odessa I.I. Mechnikov National University, Odessa, Ukraine \\ Email: *mudiep@ns.sympatico.ca
}

Received October 6, 2013; revised October 31, 2013; accepted November 16, 2013

Copyright (C) 2014 Peta J. Mudie et al. This is an open access article distributed under the Creative Commons Attribution License, which permits unrestricted use, distribution, and reproduction in any medium, provided the original work is properly cited. In accordance of the Creative Commons Attribution License all Copyrights (C) 2014 are reserved for SCIRP and the owner of the intellectual property Peta J. Mudie et al. All Copyright (C) 2014 are guarded by law and by SCIRP as a guardian.

\section{ABSTRACT}

Dating of major sea-level changes using shells or calcareous microfossils is prone to errors in semi-enclosed marine environments where inputs of seawater and river water vary over time and space. The need to refine mollusc-based age estimates for the rate of the Holocene marine transgression in the Black Sea is the focus of multiple palaeoceanographic and archaeological studies. This ongoing "dating game" seeks to clarify conflicting evidence for a hypothetical catastrophic marine flood that forced the emigration of Neolithic farmers from the shores of a Holocene freshwater lake in the Black Sea. The potential importance of confirming or rejecting this megaflood hypothesis has led to multiple attempts at refining the chronology of the marine transgression and quantifying the palaeosalinity of the Black Sea surface water during the Holocene. Here we report that six new AMS radiocarbon ages of $8890 \pm 50$ to $8450 \pm 40 \mathrm{yr}$ BP were obtained for wood, grass and sedge leaves from peat layers in Core 342 at 33.16 - $32.71 \mathrm{~m}$ below present sea level on the Ukrainian Shelf. These plant materials provide critical new ages for quantifying Black Sea carbon reservoir issues. The accuracy of our new AMS wood/peat ages is independently supported by palynochronological correlation. The ages of our plant materials have $\sim 100$ years precision and are $\sim 420$ - 520 years younger than those previously reported for unsorted detrital peat in Core 342. Paired mollusc — wood ages for brackish-freshwater Dreissena polymorpha shell from detrital peat also shows that an inaccuracy of $>1120$ yr can arise for shells during times when carbon reservoir values in the semi-isolated, brackish-water Black Sea could depart significantly from global average. Our revised sea level curve shows a gradual early Holocene transgression from water depths of -45.9 to $-32.8 \mathrm{~m}$, with initial Mediterranean inflow by 8.9 ka BP.

\section{KEYWORDS}

\section{Radiocarbon Age; Carbon Reservoir; Delta Peat; Brackish Molluscs; Palynology}

\section{Introduction}

For two decades, the timing and rate of Holocene marine transgression in the Black Sea (Figure 1) has been the focus of palaeoecological and archaeological studies $[1,2]$. The idea of a catastrophic marine flood that forced the rapid emigration of Neolithic farmers from exposed shelves of a Holocene freshwater lake was equated with the legend of Noah's Flood [3,4], despite lack of direct archaeological evidence [5]. The potential importance of confirming or rejecting this hypothesis by refining the

\footnotetext{
"Corresponding author.
}

chronology of the marine transgression and quantifying the surface water palaeosalinity [6] is the aim of many recent Black Sea palaeoceanographic studies [1,7-19]. The center of the scientific controversy largely involves validation of the in-situ positions and the carbon reservoir age corrections used to date molluscs and to determine an extremely rapid (catastrophic) or "prompt" Holocene flooding of the Ukrainian Shelf $[3,4]$ and the paleo-Danube Delta [16].

Related critical issues are 1) determining the depth of the Black Sea water level at the time of the marine reconnection, and 2) measuring the paleosalinity of the 


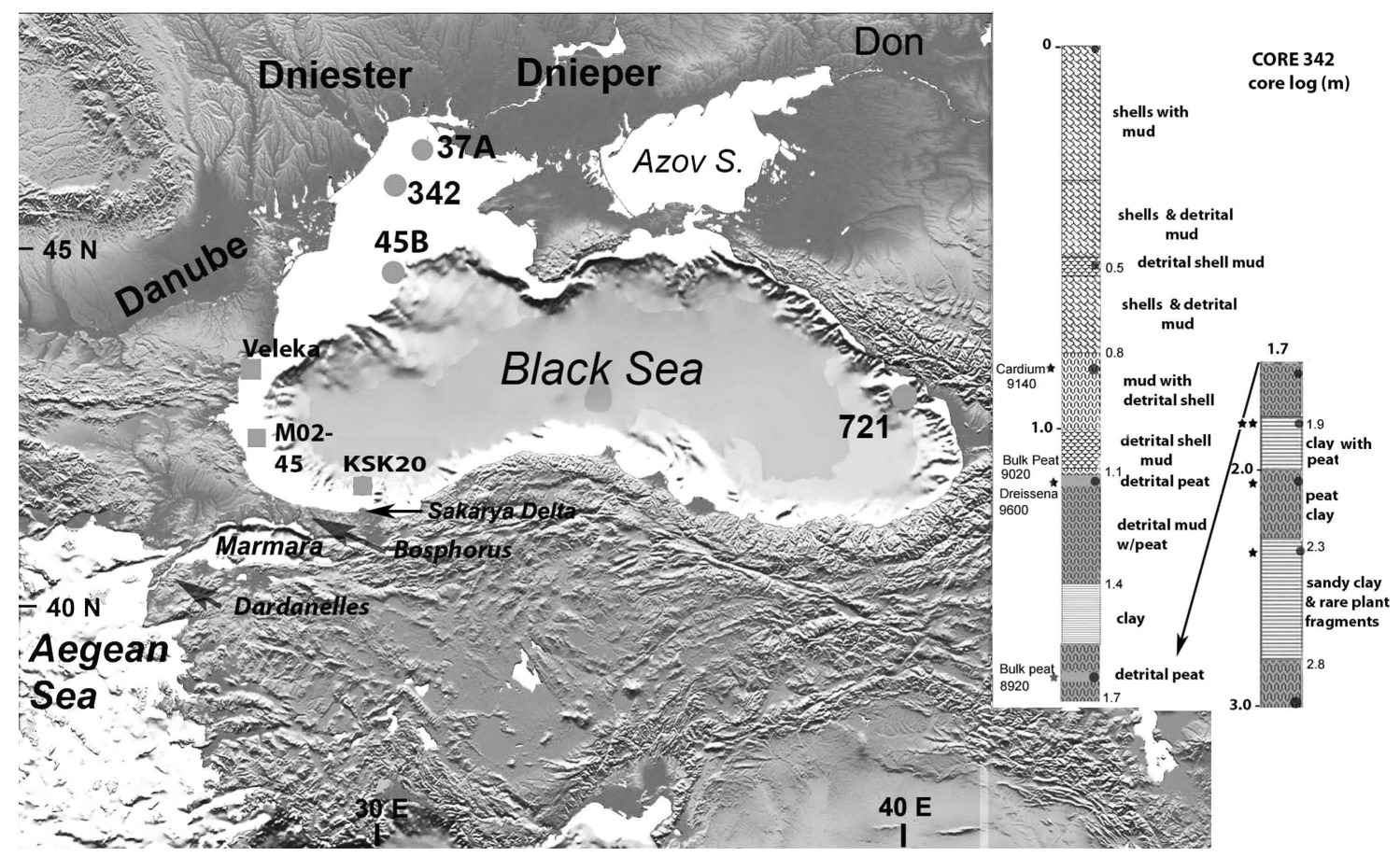

Figure 1. Map of study area showing locations of Odessa University-Prichernomor GRGP cores (dots) and other key core sites mentioned in the text (squares) or in Supplementary Data. Inset shows the core lithology and published AMS radiocarbon ages (conventional radiocarbon years $\mathrm{BP}$ ).

surface water layer $(0$ - $100 \mathrm{mbsl})$ to determine the amount of marine inflow and mixing of "old" bottom water and "new" surface water in this strongly stratified marine basin. Today, the microtidal Black Sea is a $>2$ km-deep, almost land-locked anoxic basin connected to the Eastern Mediterranean Sea and global ocean (Figure 1) only through the $\sim 2 \mathrm{~km}$-wide, shallow Bosphorus Strait (59 - 38 mbsl depth), the Marmara Sea, and the Dardanelles Strait (sill depth $72 \mathrm{~m}$ ). A positive estuarine water circulation is driven by inflow of saline ( $\sim 35 \mathrm{psu})$ bottom water of Mediterranean origin and outflow of low salinity ( 18) surface water [6] formed by mixing of bottom water with freshwater runoff [9], primarily from the Danube, Dniester, Dnieper and Don rivers (totaling $294-474 \mathrm{~km}^{3} \cdot \mathrm{a}^{-1}$ ). However, throughout the period of low global sea level during and for several millennia after the last glaciation, the Black Sea was an isolated lacustrine environment with surface salinity less than 8 $10[2,6]$ until Mediterranean waters began breaching the Bosphorus $\sim 10$ - 9 ka BP where BP = before present, taken as calendar year $1950[6,10]$. It is frequently assumed that before the event Soulet et al. labeled as "initial marine inflow" (IMI) of Mediterranean water at $\sim 8400$ yr BP ( 9400 cal yr BP) [12], the Black Sea surface water $(0-400 \mathrm{~m})$ was fully mixed, with a fluviatile geochemical signal $[11,12]$ and that it supported freshwater/brackish benthic faunas [2,11], thus requiring no reservoir age, correction. However, divergent AMS (Accelerator Mass Spectometry) ages for an unspecified peat sample and single valve of a brackish-water mollusc, Dreissena polymorpha, at 31.95 mbsl (1.1 m in Core 342, Figure 1; Table 1) suggest a possible carbon reservoir age (R) of 600 years for the shell [7] and indicate a strong influence of carbonate dissolution from surrounding watersheds.

In a region-wide review of radiocarbon ages, Soulet et al. [11] determined a mean reservoir age of $300 \pm 125$ years for the Black Sea at the start of the IMI. Between the IMI and the "disappearance of lacustrine species" (DLS event) around $7580 \mathrm{yr}$ BP [11], the salinity of surface water measured quantitatively from dinoflagellate cysts [6] increased gradually, not abruptly, as did the bottom-water microfaunal salinities [2,8]. Comparison of paired mollusc and peat ages from the Sakarya coastal plain suggested that a mean $R$ of $350 \pm 260$ years was an appropriate regional reservoir age for shells during the DLS [11]. After 7100 yr BP, when salinity reached essentially modern values, a marine reservoir value of 415 years is uniformly applied to the dating of Black Sea molluscs [6,13], while modern shell ages range from 498 308 years [14].

Correct reconstruction of the timing of the marine reconnection and transgression depends on the validity of the estimated differences between Black Sea water reservoir values and the contemporary atmospheric radiocarbon content. Evaluations of Black Sea mollusc carbon reservoir ages rely mainly on calibration against wood or peat samples presumed to be in situ on a shore 
Table 1. Core 342 AMS radiocarbon dating results for plant material selected from peat samples, in conventional years BP with 1 standard deviation ( $68 \%$ probability), $\delta^{13} \mathrm{C}$ values relative to PDB-1, and cal yr BP determined from the INTCAL09 record.

\begin{tabular}{|c|c|c|c|c|c|c|}
\hline LAB No. & $\begin{array}{c}\text { Material } \\
\text { and Core depth }(\mathrm{cm})\end{array}$ & Material Pretreatment & Measured Age & $\begin{array}{c}{ }^{13} \mathrm{C} /{ }^{12} \mathrm{C} \\
\end{array}$ & $\begin{array}{c}\text { Conventional Age } \pm 1 \\
\text { s.d. }\end{array}$ & $\begin{array}{c}\text { Cal yr BP } \\
2 \text { Sigma Calibration }\end{array}$ \\
\hline $\begin{array}{c}\text { BETA } \\
318167\end{array}$ & $\begin{array}{l}\text { WOOD } \\
237\end{array}$ & $\begin{array}{l}\text { acid/alkali/ } \\
\text { acid }\end{array}$ & $8860+/-40 \mathrm{BP}$ & -25.9 & $8850+/-40 \mathrm{BP}$ & $10160-9740$ \\
\hline $\begin{array}{c}\text { BETA } \\
328090\end{array}$ & $\begin{array}{l}\text { SILTY PEAT } \\
235\end{array}$ & Acid washes & $9040+/-40 \mathrm{BP}$ & -27.8 & $8990+/-40 \mathrm{BP}$ & $\begin{array}{c}10230-10160 \\
9980-9970\end{array}$ \\
\hline $\begin{array}{c}\text { BETA } \\
327305\end{array}$ & $\begin{array}{c}\text { WOODY } \\
\text { PEAT } \\
235\end{array}$ & $\begin{array}{l}\text { Acid/alkali/ } \\
\text { acid }\end{array}$ & $8780+/-50 \mathrm{BP}$ & 27.7 & $8740+/-50 \mathrm{BP}$ & $9910-9550$ \\
\hline $\begin{array}{c}\text { BETA } \\
318166\end{array}$ & $\begin{array}{l}\text { WOOD } \\
212\end{array}$ & $\begin{array}{l}\text { Acid/alkali/ } \\
\text { acid }\end{array}$ & $8910+/-50 \mathrm{BP}$ & -26.2 & $8890+/-50 \mathrm{BP}$ & $10190-9770$ \\
\hline $\begin{array}{c}\text { BETA } \\
315423\end{array}$ & $\begin{array}{l}\text { WOOD } \\
190\end{array}$ & $\begin{array}{l}\text { Acid/alkali/ } \\
\text { acid }\end{array}$ & $8470+/-40 \mathrm{BP}$ & -26.1 & $8450+/-40 \mathrm{BP}$ & $9530-9430$ \\
\hline $\begin{array}{c}\text { BETA } \\
315422\end{array}$ & $\begin{array}{l}\text { LEAF } \\
190\end{array}$ & $\begin{array}{l}\text { Acid/alkali/ } \\
\text { acid }\end{array}$ & $8570+/-40 \mathrm{BP}$ & -26.2 & $8550+/-40 \mathrm{BP}$ & $9550-9490$ \\
\hline $\begin{array}{l}\text { OZL } \\
581\end{array}$ & $\begin{array}{c}\text { Detrital PEAT } \\
165\end{array}$ & n.d. & n.d. & -28.1 & $8920 \pm 70 \mathrm{BP}$ & \\
\hline $\begin{array}{l}\text { OZL } \\
579\end{array}$ & $\begin{array}{c}\text { Dreissena } \\
\text { polymorpha } \\
115\end{array}$ & n.d. & n.d. & -8.7 & $9620 \pm 60 \mathrm{BP}$ & \\
\hline $\begin{array}{l}\text { OZL } \\
577\end{array}$ & $\begin{array}{l}\text { Detrital PEAT } \\
115\end{array}$ & n.d. & n.d. & -24.9 & $9020 \pm 70 \mathrm{BP}$ & \\
\hline
\end{tabular}

line [7,11,13-15], although there are other attempted calibration methods: tuning by cross-correlation of geochemical records [12]; thermoluminescence [16] and amino acid racemisation (AAR) dating [1,7]. In our new study, we have made use of sediments from the top section of the $72.5 \mathrm{~m}$-long Core 342 from $30.8 \mathrm{mbsl}$ on the Ukrainian Shelf (Figure 1) which is extraordinarily valuable because it contains several peat and muddy peat beds, each up to $\sim 10 \mathrm{~cm}$ thick, inter-layered in a coastal succession with mud, clay, and shell coquina [8]. We have used these peat samples to separate identifiable wood and terrestrial plant materials for AMS dating of materials in equilibrium with the early Holocene atmosphere and free from problems of uncertain marine reservoir correction values (Table 1). Presence of shells from sediments enveloping the peats provides a chance to measure the difference in radiocarbon ages of paired plant-shell materials which provides an index of the regional HWE reservoir values. We have also assembled data from other Black Sea shelf/estuarine cores (Figure 1) with apparently in-situ peat or wood, including the eastern Sukhami Bay Core 721[ -42 mbsl; 1,2], the southern Sakarya coastal plain [13], and from 5 - 7 mbsl off Veleka Estuary in the west $[17,18]$. These new data (see Supplementary Table) are then compared with other published mollusc and detrital peat ages used by Nicholas et al. [1] to compile a composite sea level curve for the Black Sea and to calibrate AAR ages for 66 Black Sea shell samples. The two curves allow us to re-evaluate the
Nicholas et al. conclusion that the Holocene marine transgression in the Black Sea was prompt ( 400 years).

\section{Methods}

Core 342 was recovered from the inner Ukrainian Shelf by rotary drilling, as described by Yanko-Hombach et al. [8] who also outlined the geomorphological setting and lithology. For our new study of Core 342, we made palynological and micropaleontological analyses of the peats and associated sediments, and obtained AMS ages for plant materials carefully separated from the organic mud/ clay matrix (Table 1). Palynological analyses were made on samples of $5 \mathrm{~g}$ dry weight which were processed for optimal recovery of pollen, terrestrial plant spores and dinoflagellate cysts using standard methods for marine paynology $[8,20]$. Pollen records were analysed using constrained cluster analysis statistics (CONISS) and palynostratigraphic correlation was made using the chart of Filipova-Marinova et al. [18,21]. We also examined algal and fungal spores, zoomorphs, micro-charcoal and other kerogen to assist in determining the paleosalinity of the peat deposits and the sources of associated clastic sediment (Figure 2). Plant material for AMS dating was extracted by sieving at mesh sizes $2 \mathrm{~mm}, 250$ and $63 \mu \mathrm{m}$, then thoroughly washing the extracted sand-sized plant fragments which were sorted into leaves (predominantly grass and sedge) and woody twig fragments. The plant fragments [8] were identified by transmitted light microscope studies, using illustrations and descriptions of Gale 


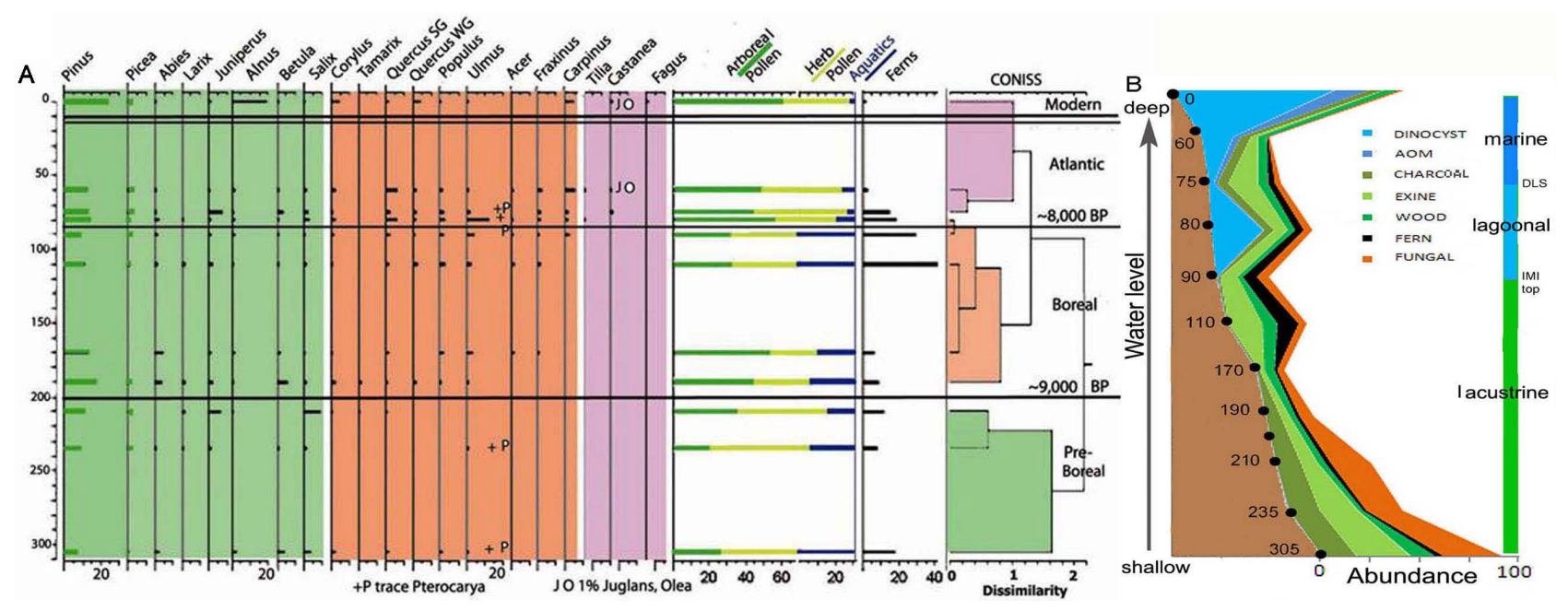

Figure 2. Core 342 palynological data. A. Pollen diagram, showing main indicator tree pollen taxa as \% total pollen, and fern spores as \% total pollen + spores, zoned by CONISS cluster analysis, and related to regional palynozones [18,21]; Quercus-s and -w: summergreen and wintergreen oaks; B. Sketch of changes in abundances/microgram of sporomorphs and other refractive particulate organic matter accompanying rising water level and salinity at Site 342 , from $33.8 \mathrm{mbsl}$ at $\sim 9.0 \mathrm{ka}$ (when water depth at the coastal site was very shallow) to present. AOM = amorphous organic matter; IMI = initial marine inflow; DLS = disappearance of "lacustrine" species.

and Cutler [22]. Radiocarbon dating was carried out on samples of $>250 \mathrm{mg}$ weight by Beta Analytical Laboratory and results are reported in Table 1 as both conventional yrs BP and calibrated ages (using the IntCal 09 record).

For micropaleontological studies of foraminifera and ostracodes, samples (50 g weight) were soaked and washed in distilled water, sieved on a $63 \mu \mathrm{m}$-mesh, dried at room temperature, and split by microsplitter. About 300 fossil foraminifera and ostracoda were hand-picked for ecostratigraphic analysis; sources of identification and illustrations of key species are given by Yanko-Hombach et al. [8]. The microfossils are grouped by ecological preference as oligohaline (1 - $5 \mathrm{psu})$, strictoeuryhaline (11 26 psu), polyhaline (18 - 26 psu), holeuryhaline (1 - 26 psu).

\section{Results and Discussion}

Our study of the herb pollen assemblages and associated leaf material study shows that the peat from $3.05-1.7 \mathrm{~m}$ in Core 345 generally represents sedge and sedge-cattail marsh with an undercover of marsh fern (Thelypteris palustris), and areas of open water with floating aquatics, as found in the modern Danube Delta [23]. CONISS cluster analysis of the tree pollen assemblages (Figure 2) reveals three palynozones: preBoreal Pinus-Picea woodland older than $\sim 9$ ka $[18,20]$ from 3.05 - $1.90 \mathrm{~m}$; Boreal phase Pinus-Picea-Quercus-Ulmus forest until $\sim 8 \mathrm{ka}$ ( 1.9 - $0.8 \mathrm{~m}$ ); and Atlantic forest with thermophilic trees Carpinus, Castanea, Tilia, Juglans and Olea. Dinoflagellate cysts of Spiniferites cruciformis and Pyxidinopsis psilata (the brackish assemblage) and Pinus-Picea-Ul- mus pollen assemblages establish the age of the youngest peat as $>7500$ yr BP $[10,18]$. Micropaleontogy (ostracoda, foraminifera) and molluscs from Core 342 and Core 45B show that the Holocene marine transgression involves a rise from $\sim 47.0 \mathrm{mbsl}$, when the paleo-Dniester Delta was an alluvial plain with freshwater ponds that were transformed into limans (32.3 - 31.65 mbsl) after the IMI, terminating in the modern low-salinity conditions of the Ukrainian Shelf [8]. Microfauna in Core 342 also show three depositional environments: semi-freshwater ponds in the Paleo-Dniester delta (core depth 3.07 - $2.1 \mathrm{~m}$ ), brackish Paleo-Dniestrovian liman conditions (2.0 $-0.83 \mathrm{~m})$, and semi-marine inner shelf paleoenvironment $(0.82-0.0 \mathrm{~m})$. Brackish conditions are indicated by oligohaline (1 to $5 \mathrm{psu}$ ) and holeuryhaline (salinity 1 $26 \mathrm{psu}$ ) foraminifera [8]. Presence of holeuryhaline species among the foraminiferal assemblage starting from the bottom of the core indicates an influence of Mediterranean water from $8.9 \mathrm{ka}$ BP upwards.

Our new AMS-dated peat samples are from clayey black peats with charred wood fragments at $2.35-2.37 \mathrm{~m}$ and $2.10-2.12 \mathrm{~cm}$, overlain by clay with peat stringers $(1.90-1.92 \mathrm{~m})$. These lowest peats have the highest percentages of of submergent and floating pondweeds ( $M y-$ riophyllum, Nymphaea, Lemna and Azolla), and the emergent aquatics are sedges and Sagittaria, indicating lower delta ponds with moderately clear water. Charred wood from the two of the black peats $25 \mathrm{~cm}$ apart have $\delta^{13} \mathrm{C}$ values (-25.9 to $-26.2 \%$ ) similar to the values of Scirpus sedges found in freshwater low marshes elsewhere [24]; the wood ages of $8850 \pm 40-8890 \pm 50 \mathrm{yr}$ BP establish a rapid accumulation rate typical for transgressive silty 
peats [25]. Comparison of ages from the wood and detrital organic silt extracted from the peat at $250 \mathrm{~cm}$, however, reveals that a the organic silt is 250 years older than the plant fragments from the same sample, despite repeated acid treatment to remove a whitish coating (possibly indicating calcareous residue).

At $\sim 1.90 \mathrm{~m}$, the aquatic pollen assemblages record cattail swamp peat and open water with Myriophyllum; Salicornia pollen and $\delta^{13}$ values of $-26.15 \%$ indicate a slightly brackish (2 - 4 psu) coastal pond environment bordered by saltflats. AMS ages for the leaves and wood are $8550 \pm 40$ and $8450 \pm 40 \mathrm{BP}$, respectively, differing insignificantly at $95 \%$. Proximity of the ages and $\delta^{13} \mathrm{C}$ values of the two terrestrial plant sources shows this peat layer was in situ and unbiased by a HWE.

Our new data based on carefully isolated plant materials on the peat layers of Core 342 can be compared with previous AMS dating [1,7] of bulk unspecified peat from $1.6-1.7 \mathrm{~m}$ and $1.1-1.2 \mathrm{~m}$, which provided older ages of $8920 \pm 60$ and $9020 \pm 70$ yr BP respectively, and displayed an age reversal of up to 230 years over this $~ 50$ $\mathrm{cm}$ depositional interval (uncorrected for compaction). Our palynological inspection of the peat at $1.70 \mathrm{~m}$ shows sedge, grass and wood fragments which are consistent with a freshwater $\delta^{13}-28.1 \%$ signal [7]; however, the clastic matrix of the plant materials contained abundant Glomus chlamydospores which are indicative of terrigenous sediment erosion [22], hence old carbon contamination. Our study of the uppermost detrital peat at 1.11 m shows fragments of sedges, spike rush, Phragmites reeds, and again, common Glomus chlamydospores which suggest influx of eroded sediment from upstream sources. This peat has a $\delta^{13} \mathrm{C}$ value of $-24.9 \%$ [7] which is high for $\mathrm{C}_{3}$ plant taxa such as sedges and rushes, and suggests contamination from marine carbon. A Dreissena shell valve from this peat layer at $\sim 1.1 \mathrm{~m}$ core-depth was dated $9620 \pm 60$ yr BP [11]. If in place, comparison of the paired shell versus peat ages implies a $600 \mathrm{yr}$ hardwater effect (HWE) for the pre-DLS time, which is at the upper limit of the average HWE range determined by Soulet et al. [11].

In summary, our AMS age of 8450 - 8550 yr BP for leaves and wood at 32.7 mbsl on the Ukrainian shelf provides a new datum for evaluating the Black Sea shelf water HWE in shells during the lacustrine pre-IMI phase and it also shows that the radiocarbon ages of undifferentiated muddy peat samples can be too old by $250-425 \mathrm{yr}$. A Dreissena shell from $76 \mathrm{~cm}$ from above the peat datum is older by $1125 \mathrm{yr}$. The latter value is consistent with an HWE estimate of $\sim 1000 \mathrm{yr}$ for pre-Holocene shelf water [19] and with the common reworking of small shells reported for transgressive shorelines, as in the paleo-Danube Delta [16]. The older AMS ages [7] of $8920 \pm 60$ and $9020 \pm 70$ for the bulk muddy peat samples taken from levels above our peat datum corresponds to presence of common fungal spores indicating redeposition from upstream basin erosion and probable contamination by reworked sedimentary carbon and plant debris.

Further discussion focuses on comparison with the work of Nicholas et al. [1] who used $>50$ conventional ${ }^{14} \mathrm{C}$ and AMS ages from bulk undifferentiated peat and mollusc ages 1) to produce a composite sea level curve for the Black Sea; 2) to calibrate their AAR ages; and 3) to conclude that the Holocene marine transgression was "prompt" but not catastrophic. Here we show that their curve fits within the $95 \%$ confidence prediction interval for a regression line fitting 43 ages obtained for peat and selected liman shell/organic mud samples from the Ukrainian Shelf (Figure 3). Note that the Nicolas et al. [8] record is strongly skewed towards the oldest bulk peat

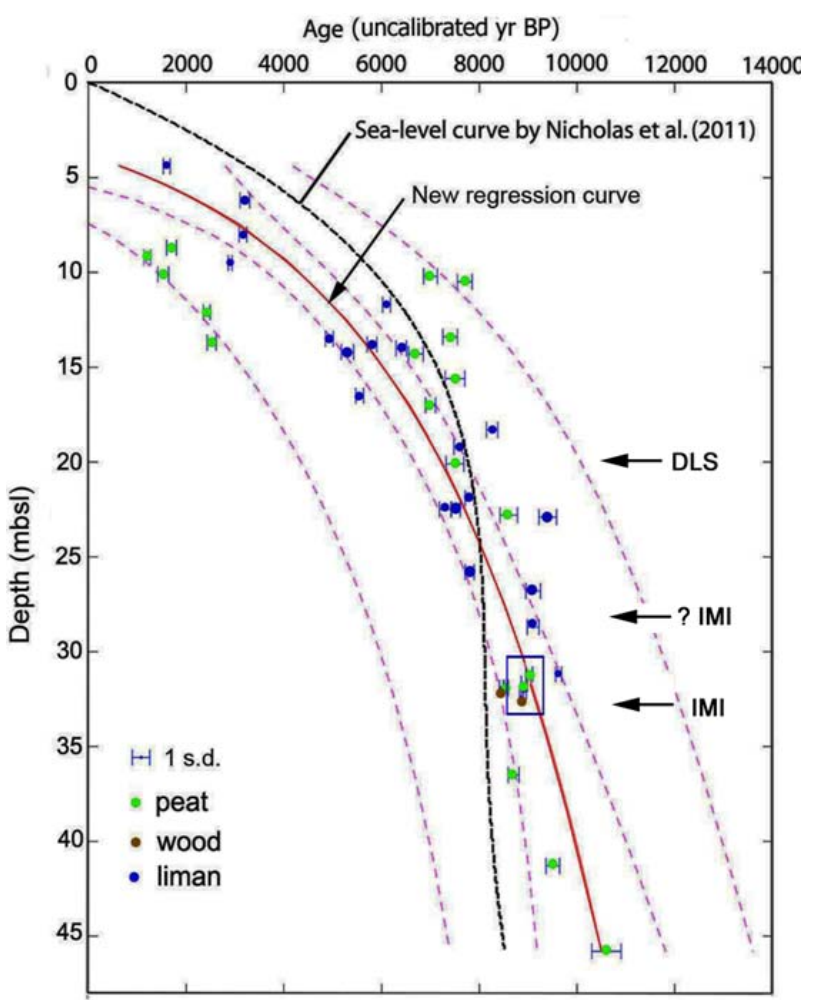

Figure 3. Composite sea level record (solid red line) in ${ }^{14} \mathrm{C}$ yr BP, based on the best-fit multiple regression line for all available peat and liman shell ages (see Supplement 1) for the Ukrainian Shelf, with its confidence interval (inner pink dashes) and the prediction envelope (outer pink dashes) delimiting the area within which an unknown sample is expected to fit with $95 \%$ confidence. Dashed black line is the record of Nicholas et al. [10], 2011. Whiskered bars show 1 standard deviation (68\% probability) for ages, with depth errors being less than the verticals. Small rectangle encloses the new AMS peat and wood ages and shows the significantly earlier and slower transgression compared to the values reported previously [1,3]. IMI marks our new position for the initial Mediterranean water inflow, compared to IMI? and DLS which are the datums of Soulet et al. [11]. 
ages at the edge of our 2 s.d. prediction envelope from $\sim 8$ - $4 \mathrm{ka}$. Our new record more accurately represents the average gradual rise of water in the Black Sea from 45.9 mbsl at $10,600 \pm 300 \mathrm{yr} B P$ to 4 mbsl at $1200 \pm 70 \mathrm{yr} \mathrm{BP}$, excluding intervals $\sim 5-3.5 \mathrm{ka}$ and the Phanagorian regression ( 2.8 - $2 \mathrm{ka}$ ) where we have no peat data. Our microfossil records [8] also indicates that the Bosphorus sill was deeper than 30 mbsl around 8.9 ka at the Holocene IMI, as also reported for the SW Black Sea shelf $[6,10]$ and at the time of initial liman formation [19]. Our new data, combined with previous shelf-wide studies [8] show that from $9.5-8.5 \mathrm{ka}$, water rose gradually $(\sim 1.7$ $\mathrm{cm} \mathrm{a}^{-1}$ ) over the Ukrainian shelf from $45.9-32.8 \mathrm{mbsl}$, at rates similar to historical values and without evidence of early Holocene catastrophic flooding, and it requires re-setting of Soulet's [11] IMI age of $\sim 8.4$ ka BP to 8.9 ka BP.

\section{Conclusion}

We have contributed to the refinement of the Black Sea scientific "dating game" by obtaining six new AMS radiocarbon ages of $8890 \pm 50$ to $8450 \pm 40 \mathrm{yr}$ BP on wood and sedge leaves from the paleo-Dneister Delta, from 33.17 - 32.71 mbsl on the Ukrainian Shelf. The plant materials from outer delta coastal settings provide new reference points for re-evaluation of shell and bulk peat ages reported for early Holocene Black Sea sediments. The accuracy of our AMS wood/peat ages is independently supported by palynochronological correlations which are tied to vegetation-based chronologies in regional upland lakes. Our AMS ages of identified plant materials from Core 342 have $\sim 100$ years precision and are $\sim 420$ - 520 years younger than previously reported ages from unspecified detrital peat located higher in the same core. Paired peat-shell ages for brackish-freshwater Dreissena polymorpha shell in the detrital peat, also show that an inaccuracy of $>1120 \mathrm{yr}$ can arise for shells during times when carbon reservoir values in the semiisolated, brackish-water Black Sea could depart significantly from global average. We advocate that careful extraction and assessment of suitable plant materials needs to be applied to peat samples selected for AMS dating, and we provide a new composite Black Sea sea-level record which shows that from $10.6-8.5 \mathrm{ka} \mathrm{BP}$, water rose gradually $\left(\sim 1.7 \mathrm{~cm} \mathrm{a}^{-1}\right)$ from $45.9-32.8$ mbsl over the Ukrainian shelf, at rates similar to modern recorded values. Microfossil data from Core 342 also indicate a need to reset the Black Sea IMI of Soulet et al., [11] to 8.9 kyr BP.

\section{REFERENCES}

[1] W. A. Nicholas, A. R. Chivas, C. V. Murray-Wallace and D. Fink, "Prompt Transgression and Gradual Salinisation of the Black Sea during the Early Holocene Constrained by Amino Acid Racemization and Radiocarbon Dating," Quaternary Science Reviews, Vol. 30, No. 27, 2011, pp. 3769-3790.

[2] V. Yanko-Hombach, "Controversy over Noah's Flood in the Black Sea: Geological and Foraminiferal Evidence from the Shelf,” In: V. Yanko-Hombach, et al., Ed., The Black Sea Flood Question: Changes in Coastline, Climate and Human Settlement, Springer, Dordrecht, 2007, pp. 149-203. http://dx.doi.org/10.1007/978-1-4020-5302-3_7

[3] W. B. F. Ryan, W. C. Pitman III, C. O. Major, K. Shimkus, V. Moskalenko, J. A. Jones, P. Dimitrov, N. Görür, M. Sakinç and H. Yüce, “An Abrupt Drowning of Black Sea Shelf,” Marine Geology, Vol. 138, No. 1, 1997, pp. 119-126. http://dx.doi.org/10.1016/S0025-3227(97)00007-8

[4] C. S. M. Turney and H. Brown, "Catastrophic Early Holocene Sea Level Rise, Human Migration and the Neolithic Transition in Europe,” Quaternary Science Reviews, Vol. 26, No. 17-18, 2007, pp. 2036-204.

http://dx.doi.org/10.1016/j.quascirev.2007.07.003

[5] P. M.Dolukhanov, S. V. Kadurin and E. P. Larchenkov, "Dynamics of the Coastal North Black Sea Area in Late Pleistocene and Holocene and Early Human Dispersal," Quaternary International, Vol. 197, No. 1-2, 2009, pp. 27-34. http://dx.doi.org/10.1016/j.quaint.2008.04.002

[6] K. N. Mertens, L. R. Bradley, Y. Takano, P. J. Mudie, F. Marret, A. E. Aksu, R. N. Hiscott, T. J. Verleye, E. A. Mousing, L. L. Smyrnova, S. Bagheri, M. Mansor, V. Pospelova and K. Matsuoka, "Quantitative Estimation of Holocene Surface Salinity Variation in the Black Sea Using Dinoflagellate Cyst Process Length,” Quaternary Science Reviews, Vol. 39, 2012, pp. 45-59. http://dx.doi.org/10.1016/j.quascirev.2012.01.026

[7] W. A. Nicholas, A. R. Chivas, S. Kadurin, C. V. Murray-Wallace and D. Fink, "Chronology of an Early Holocene Transgressive Black Sea,” In: A. Gilbert and V. Yanko-Hombach, Eds., Extended Abstracts of the 5th Plenary Meeting and Field Trip of IGCP-521-INQUA 0501 Programs, Izmir-Çanakkale, 22-31 August 2009, pp. 129-131.

[8] V. Yanko-Hombach, P. J. Mudie, S. Kadurin and E. Larchenkov, "Holocene Marine Transgression in the Black Sea: New Evidence from the Northwestern Black Sea Shelf,” Quaternary International, 2013, pp. 1-19. http://www.sciencedirect.com/science/article/pii/S104061 $\underline{82130044266}$

[9] N. V. Esin, V. Yanko-Hombach and O. N. Kukleva, "Mathematical Model of the Late Pleistocene and Holocene Transgressions of the Black Sea," Quaternary International, Vol. 225, No. 2, 2010, pp. 180-190. http://dx.doi.org/10.1016/j.quaint.2009.11.014

[10] R. N. Hiscott, A. E. Aksu, P. J. Mudie, F. Marret, T. Abrajano, M. A. Kaminski, J. Evans, A. I. Çakiroğlu and D. Yaşar, “A Gradual Drowning of the Southwestern Black Sea Shelf: Evidence for a Progressive Rather than Abrupt Holocene Reconnection with the Eastern Mediterranean Sea through the Marmara Sea Gateway," Quaternary International, Vol. 167-168, 2007, pp. 19-34. 
http://dx.doi.org/10.1016/j.quaint.2006.11.007

[11] G. Soulet, G. Ménot, V. Garreta, F. Rostek, S. Zaragosi, G. Lericolais and E. Bard, "Black Sea 'Lake' Reservoir Age Evolution Since the Last Glacial-Hydrologic and Climatic Implications,” Earth Planetary Science Letters, Vol. 308, No. 1-2, 2011, pp. 245-258.

http://dx.doi.org/10.1016/j.epsl.2011.06.002

[12] A. Bahr, F. Lamy, H. W. Arz, C. O. Major, O. Kwiecien and G. Wefer, "Abrupt Changes of Temperature and Water Chemistry in the Late Pleistocene and Early Holocene Black Sea,” Geochemistry, Geophysics, Geosystems, Vol. 9, No. 1, 2008, Article ID: Q01004. http://dx.doi.org/10.1029/2007GC001683

[13] N. Gőrur, N. Cağatay, O. Emre, B. Alpar, M. Sakinç, Y. Islamoğlu, O. Algan, T. Erkal, M. Keser, R. Akkok and G. Karlik, "Is the Abrupt Drowning of the Black Sea Shelf at Myth?” Marine Geology, Vol. 176, No. 1, 2001, pp. 6573. http://dx.doi.org/10.1016/S0025-3227(01)00148-7

[14] G. Siani, M. Paterne, M. Arnold, E. Bard, B. Métivier, N. Tisnerat and F. Bassinot, "Radiocarbon Reservoir Ages in the Mediterranean Sea and Black Sea,” Radiocarbon, Vol. 42, No. 2, 2000, pp. 271-280.

[15] H. Brückner, D. Kelterbaum, O. Marunchak, A. Porotov, and A. Vött, "The Holocene Sea Level Story Since 7500 BP-Lessons from the Eastern Mediterranean, the Black and the Azov Seas,” Quaternary International, Vol. 225, No. 2, 2010, pp. 160-179. http://dx.doi.org/10.1016/j.quaint.2008.11.016

[16] L. Giosan, J. P. Donnelly, S. Constantinescu, F. Filip, I. Ovejanu, A. Vespremeanu-Stroe, E. Vespremeanu and G. A. T. Duller, "Young Danube Delta Documents Stable Black Sea Level Since the Middle Holocene: Morphodynamic, Paleogeographic, and Archaeological Implications,” Geology, Vol. 34, No. 9, 2006, pp. 757-760. http://dx.doi.org/10.1130/G22587.1

[17] M. Filipova-Marinova, L. Giosan, H. Angelova, A. Preisinger, Pavlov and S. Vergiev, "Palaeoecology of Submerged Prehistoric Settlements in Sozopol Harbour, Bulgaria,” In: J. Benjamin, et al., Eds., Submerged Prehistory, Oxbow Books, Oxford, 2011, pp. 230-244.

[18] M. Filipova-Marinova, "Palynostratigraphy of Pleistocene and Holocene Sediments from the Western Black
Sea,” Journal Environmental Microbiolog, Micropaleontology, Meiobiology, Vol. 3, 2006, pp. 9-13.

[19] O. Kwiecien, H. W. Arz, F. Lamy, S. Wulf, A. Bahr, U. Röhl and G. H. Haug, "Estimated Reservoir Ages of the Black Sea Since the Last Glacial,” Radiocarbon, Vol. 50, No. 1, 2008, pp. 99-118.

[20] P. J. Mudie, S. A. G. Leroy, F. Marret, N. P. Gerasimenko, S. E. A. Kholeif, T. Sapelko and M. Filipova-Marinova, "Nonpollen Palynomorphs: Indicators of Salinity and Environmental Change in the Caspian-Black SeaMediterranean Corridor,” Geological Society America Special Paper, Vol. 473, 2011, pp. 89-114. http://dx.doi.org/10.1130/2011.2473(07)

[21] K. A. Arslanov, L. A. Saveljeval, N. A. Gey, V. A. Klimanov, S. B. Chernov, G. M. Chernova, G. F. Kuzmin, T. V. Tertychnayal, D. A. Subettos and V. P. Denisenkov, "Chronology of Vegetation and Paleoclimatic Stages of Northwestern Russia during the Late Glacial and Holocene,” Radiocarbon, Vol. 41, No. 1, 1999, pp. 25-45.

[22] R. Gale and D. F. Cutler, "Plants in Archaeology: Identification Manual of Vegetative Plant Materials Used in Europe and the Southern Mediterranean to c. 1500,” Westbury Publications and Royal Botanic Gardens, Kew, 2000.

[23] H. Coops, J. Hanganu, M. Tudor and W. Oosterberg, "Classification of Danube Delta Lakes Based on Aquatic Vegetation and Turbidity," Hydrobiologia, Vol. 415, 1999, pp. 187-191. http://dx.doi.org/10.1023/A:1003856927865

[24] R. Byrne, B. L. Ingram, S. Starratt, F. Malamud-Roam, J. N. Collins and M. E. Conrad, "Carbon-Isotope, Diatom, and Pollen Evidence for Late Holocene Salinity Change in a Brackish Marsh in the San Francisco Estuary," Quaternary Research, Vol. 55, No. 1, 2001, pp. 66-76. http://dx.doi.org/10.1006/qres.2000.2199

[25] J. R. L. Allan, "Geological Impacts on Coastal Wetland Landscapes: Some General Effects of Sediment Autocompaction in the Holocene of Northwest Europe," The Holocene, Vol. 9, No. 1, 1999, pp. 1-12. http://dx.doi.org/10.1191/095968399674929672 